\title{
Analysis of the stress deformed state of rocks around the haulage roadway of the Beskempir field (Kazakhstan)
}

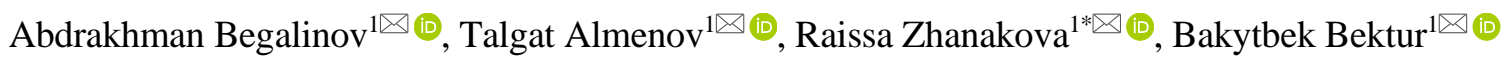 \\ ${ }^{1}$ Satbayev University, Almaty, 50013, Kazakhstan \\ *Corresponding author: e-mail zhanakova_raisa@mail.ru, tel.+77714458984
}

\begin{abstract}
Purpose. To perform research and detailed analysis of the stress deformed state of rocks around the haulage roadway based on the numerical modeling with the purpose to select the rational type and design of the haulage roadway support at the Beskempir field.

Methods. A comprehensive research method has been used: review and generalization of references related to the study of the stress deformed state of a rock mass, improvement of the walling technology, in-situ and laboratory tests in the research and testing of rock samples strength; application of mathematical statistics and processing of experimental data using software products. The numerical modeling of the stress deformed state was done using the Examine 2D application with due account for the shape of broken rocks area, which is a 138x138x138 m regular triangle. Barton's Q-system was used to the RQD assessment.

Findings. The numerical modeling of the stress deformed state of rocks in the tectonic fault zone of the haulage roadway at $+230 \mathrm{~m}$ was performed, and the rock mass deformation zones were defined around the mine contours. The charts showing displacement of roof rocks and walls of the haulage roadway were built, where it was established that the maximum displacement was manifest over the tectonic fault zone. The following zones were identified: the rock mass instability zones, the rock mass instability zones with due account for its fracturing, the zones of stable and unstable rock masses of the haulage roadway. It was established that $41.6 \%$ of the working with the fault zone is unstable, and $58 \%$ of it is a more stable part. It is proposed to divide the haulage roadway into three sections depending on the rock stability with a certain type of support.

Originality. Based on the study of the stress deformed state of the rock mass in the conditions of the Beskempir field, sitespecific unstable sections were identified. They ensured the selection of the support design with adjustable resistance.

Practical implications. The application of support with adjustable resistance depending on the rock mass stability ensures minimization of costs for roadway support, maintenance of extensive sections of the working as well as enhanced mining safety in specific mining and geological conditions of the Beskempir field.
\end{abstract}

Keywords: stress deformed state, rock mass, support, fault zone, support design, construction, tectonic faults, underground workings

\section{Introduction}

One of the main strategic tasks of independent Kazakhstan is to increase the gold and currency reserves, especially when the global financial market at times experiences turbulence and crises [1], [2]. Under these conditions, domestic monetary investments in the economy, reliability and stability of the tenge are of particular importance. In this regard, the role of the country's gold and currency reserves sharply increases. Having great potential for a significant increase in the production of precious metals due to commercial gold resources in the subsoil, as well as due to gold in man-made mineral formations, in concentration tailings and products of metallurgical treatment, Kazakhstan is far from fully using these opportunities [3], [4]. To achieve the goal of increasing gold produc- tion, it is necessary to exclude losses that occur in the process of mining and processing of gold-bearing raw materials at the stage preceding to the production of ready-to-use goods.

To increase the productivity of gold mining deposits, it is necessary to perform significant capital development [5], [6]. In addition, it is known that to increase the productivity of existing mines, it is necessary to build new levels. These mine workings are used by people to transport rock masses, to supply communication (compressed air, clean air, water supply, electric cables, etc.) systems [7]-[9].

Therefore, these mine workings are underground engineering structures. These workings should be able to maintain their design shapes and dimensions [10]-[12]. That is, during the entire life of the mine they are expected to maintain their dimensions and long-term operability [13]. Therefore, the 
selection of the optimal type of support for mine workings and the improvement of support structures by deeply studying the physicomechanical properties and geomechanical conditions of the rock mass is a mining priority.

A large contribution in assessing the state of the rock mass and support of mine workings in complex geological conditions was made by M.M. Protodyakonov, P.M. Tsymbarevich, V.D. Slesareva, N.S. Bulychev, V.Ye. Bolikov A.G. Protosenya, A.B. Makarov, M.I. Zharkenov, etc. who proposed various methods for calculating rock pressure. The patterns of rock pressure manifestations on the support were widely used for stopes. At that the pressure on the support was determined mainly using physical measurements, which reflected the field-specific features and could not be used for another field. In our case, the stability of the rock mass within the same field varies.

To create a unified model of rock behavior during underground mining, we used the representation of the consolidated rock mass states. However, the object under research falls under various categories of the rock stability.

In this regard, our studies are targeted at the study of the geomechanical state of the Beskempir deposit, classified as the gold deposits of Kazakhstan. The ores belong to the goldquartz moderate sulfide formation. Associated components are: silver and sulfide sulfur. The relief of the region is hillocky, plain with absolute elevations $+465-490 \mathrm{~m}$. The climate is sharply continental, arid, with frequent strong winds, mainly north-eastern. Summers are dry and hot; winters lacking snowfalls with frequent thaws. Stable 0.3-0.4 m snow cover lasts from December to February. The average annual temperature is $+5-6^{\circ} \mathrm{C}$. The seismicity of the area is 6 points. The principle ore-controlling structures are feathering shear fractures and ruptures. Their length is up to $2-3 \mathrm{~km}$. The inclination is multidirectional at $40-45$ to $60-85^{\circ}$. An important role in controlling the position of ore bodies belongs to dykes [13].

The weakest sections are couplings of quartz veins with ore-controlling dykes. The morphology of ore bodies, especially at the Beskempir deposit, is complex. There are many geological faults that shift ore bodies along the vertical and horizontal plane from 1 to $20 \mathrm{~m}$.

The hydrogeological conditions of the deposits are simple. There are no aquifers within or near the ore field, which excludes single concentrated discharge of water into the mine workings. Interstitial water. Actual inflow into underground workings is $15-20 \mathrm{~m}^{3} /$ hour. Groundwater is aggressive to concrete containing non-sulfide-resistant cement. Water is not carbonate aggressive.

The Beskempir gold field is located in an intense tectonic zone at the intersection of faults. The maximum disturbance of rocks is noted in the western part of the field. The Beskempir deposit is characterized by complicated, numerous variously oriented disturbances from regional faults of the ancient deposits (Kengirsky) and pre-existent second-order faults (Beskempirsky, Dolinniy, etc.) to feathering fissures, ruptures, shear fractures and fracture structures [14][15].

The present work analyzes the stress deformed state of rocks around the haulage roadway of the Beskempir deposit. The object under research, the haulage roadway, is an important object for the increase in gold production.

The total designed length of the roadway is $1200 \mathrm{~m}$. About $30 \%$ of the roadway is crossed with deformed rock mass of medium stability prone to destruction, and the re- mained length of the haulage roadway $(70 \%)$ is more stable. The roadway is dome-shaped, the cross-sectional area is $S=10.9 \mathrm{~m}^{2} \quad(L=3400 \mathrm{~mm}, \quad H=3450 \mathrm{~mm}, \quad R=2350 \mathrm{~mm}$, $r=890 \mathrm{~mm}$ ). The analysis of the mining geological and mining engineering conditions revealed that the stress deformed state of the rocks around the haulage roadway is complex. The complexity of this task is explained by the variety of rock properties over the entire length of the haulage roadway.

\section{Methods}

Road-heading in the rock mass disturbs the natural state of stress. As a result, a new state of stress is formed in the rocks surrounding the mine working, which depends both on the components of the initial stress field and the crosssectional shape of the mine working. The first attempts to determine the rock pressure on the support of underground workings were made in the second half of the nineteenth century. However, a large number of studies of the rock pressure emergence were carried out in the twentieth century. This resulted in further development of the theory of rock pressure. Researchers M.M. Protodyakonov, V.D. Slesareva, P.M. Tsimbarevich, S.G. Avershina, G.N. Kuznetsova, K.V. Ruppenyta, A.A. Barisova, F. Shpruta, A. Labassa, V. Itersovna, U. Waker, etc. proposed methods for calculating rock pressure, each using a certain concept of behavior of rocks during their underworking [16][17].

The mentioned methods ensure the determination of the stress deformed state of a rock mass near a horizontal working. With due account for the existing conditions of the researched object, we cannot determine the actual values for choosing the type of support, however, it gives estimated dependences for solving problems in the conditions of plane deformation. At the same time, it is necessary to take into account the variety (the working crosses the fault zone) of physical and mechanical properties throughout the haulage roadway.

The foregoing studies have revealed that, a special approach is necessary in the conditions of the Beskempir field, especially for the haulage roadway, since this mine working is subjected to different stresses. Therefore, the study of this problem is associated with the variety of rock properties, conditions of road-heading and occurrence of these workings as well as the geometry of the workings.

To determine the zone of the stress deformed state of the researched mass, the mining geological and mining engineering characteristics of the Beskempir field were studied. The Beskempir ore bodies are represented by quartz veins with beresite selvages in granodiorites. The hardness of the host rocks on the Professor M.M. Protodyakonov's scale is 11-14, ore hardness, 16-17. The bulk density of ore and rocks is $2.73 \mathrm{t} / \mathrm{m}^{3}$. The soil conversion factor is 1.6. The average compressive strength in granodiorites is $\sigma_{c}=135.33 \mathrm{MPa}$, in arkose sandstones $-\sigma_{c}=159.45 \mathrm{MPa}$, in quartz ores $\sigma_{c}=166.71 \mathrm{MPa}$, in beresites $-\sigma_{c}=125.32 \mathrm{MPa}$, in lamprophyres $-\sigma_{c}=90 \mathrm{MPa}$ (Table 1 ). The bulk density of ores is $2.73 \mathrm{t} / \mathrm{m}^{3}$, that of the host rocks are $2.7 \mathrm{t} / \mathrm{m}^{3}$.

The natural moisture content of rocks and ores does not exceed $1.5 \%$. The actual water inflow into underground mine workings during geological exploration was varied from 7 to $17 \mathrm{~m}^{3} /$ hour. According to calculations, the maximum expected inflow depending on the depth will be from $20 \mathrm{~m}^{3} /$ hour (level $+216 \mathrm{~m}$ ) to $32-35 \mathrm{~m}^{3} /$ hour (level $-24 \mathrm{~m}$ ). 
Table 1. Physical and mechanical properties and parameters of rocks at the Beskempir field

Physical and mechanical properties and parameters

\begin{tabular}{|c|c|c|c|c|c|c|c|c|c|c|}
\hline \multirow{3}{*}{$\begin{array}{c}\text { Number and } \\
\text { description } \\
\text { of layers }\end{array}$} & \multicolumn{5}{|c|}{ Determined using laboratory tests } & \multicolumn{5}{|c|}{ Determined using other sources } \\
\hline & 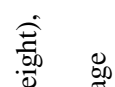 & $\begin{array}{l}\delta^{2} \\
\approx\end{array}$ & $\begin{array}{r}\text { Compress } \\
\mathrm{kg}\end{array}$ & trength, & 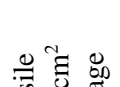 & & జే & & $\stackrel{\ominus}{\Xi}$ & 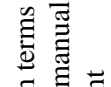 \\
\hline & 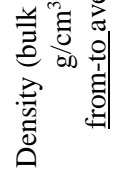 & 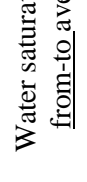 & 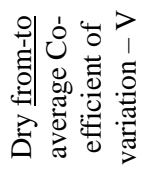 & 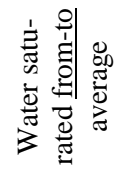 & 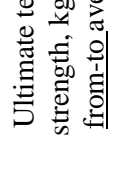 & 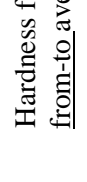 & 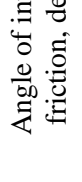 & 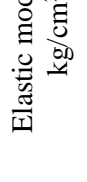 & $\begin{array}{l}n \\
\tilde{0} \\
0 \\
0 \\
0\end{array}$ & 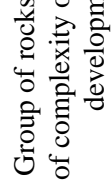 \\
\hline
\end{tabular}

Layer 1. Grayish-brown inclusion of rotten stone and gravel

Layer 2. Greenish-gray silty sandstone with thin interlayers of schistic siltstone

Layer 3. Quartz finegrained sandstone with rare intercalations of siltstone

Layer 4. Grayish-green fine-grained polymictic sandstone with rare siltstones

Layer 5. Grayish-green arkose sandstone

Layer 6. Schistic siltstone varying from greyish-white to black Layer 7. Black schistic siltstone

Layer 8. Grayish-green brecciate siltstone loam with up to $15 \%$ intercalations of

Density (bulk weight): $1.81 \mathrm{~g} / \mathrm{cm}^{3}$, dry soil density (dry unit weight): $1.66 \mathrm{~g} / \mathrm{cm}^{3}$; particle density (specific weight): $1.71 \mathrm{~g} / \mathrm{cm}^{3}$; adhesion: $0.028 \mathrm{MPa}\left(0.28 \mathrm{kgf} / \mathrm{cm}^{2}\right)$

\begin{tabular}{|c|c|c|c|c|c|c|c|c|}
\hline$\frac{2.64-2.75}{2.71}$ & $\frac{0.40-1.26}{0.6}$ & $\begin{array}{c}\frac{499-833}{651} \\
33.02\end{array}$ & $\frac{294-676}{486}$ & $\frac{51-89}{64}$ & $\frac{5.0-8.3}{6.5}$ & 30 & 26 & $\begin{array}{c}0.3 \\
1\end{array}$ \\
\hline$\frac{2.69-2.71}{2.70}$ & $\frac{0.41-0.65}{0.53}$ & $\begin{array}{c}\frac{695-1056}{832} \\
26.60\end{array}$ & $\frac{476-774}{602}$ & $\frac{51-57}{54}$ & $\frac{7.0-10.6}{8.3}$ & 33 & 56 & $\begin{array}{c}0.2 \\
5\end{array}$ \\
\hline
\end{tabular}

\begin{tabular}{|c|c|c|c|c|c|c|c|c|c|}
\hline$\frac{2.73-2.76}{2.75}$ & $\frac{0.28-0.51}{0.40}$ & $\begin{array}{c}\frac{320-560}{545} \\
4.50\end{array}$ & $\frac{215-336}{235}$ & $\frac{31-47}{41}$ & $\frac{3.2-5.6}{5.2}$ & 35 & 45 & $\begin{array}{c}0.2 \\
3\end{array}$ & VI \\
\hline$\frac{2.61-2.67}{2.64}$ & $\frac{0.51-0.80}{0.60}$ & $\frac{285-605}{515}$ & $\frac{188-350}{285}$ & $\frac{21-52}{41}$ & $\frac{2.9-6.0}{\underline{5.2}}$ & 32 & 51 & $\begin{array}{c}0.2 \\
5\end{array}$ & VI \\
\hline$\frac{2.71-2.77}{2.73}$ & $\frac{0.36-1.03}{0.60}$ & $\begin{array}{c}\frac{339-502}{385} \\
32.95\end{array}$ & $\frac{185-394}{291}$ & $\frac{15-39}{19}$ & $\frac{3.4-5.0}{3.9}$ & 28 & 15 & $\begin{array}{c}0.3 \\
3\end{array}$ & IV \\
\hline$\frac{2.71-2.80}{2.75}$ & $\frac{0.29-0.73}{0.51}$ & $\frac{255-649}{450}$ & $\frac{144-361}{310}$ & $\frac{18-49}{28}$ & $\frac{2.6-6.5}{4.5}$ & 29 & 26 & $\begin{array}{c}0.2 \\
9\end{array}$ & $\mathrm{~V}$ \\
\hline$\frac{2.72-2.77}{2.74}$ & $\frac{0.13-0.31}{0.25}$ & $\frac{377-518}{467}$ & $\frac{294-440}{345}$ & $\frac{46-54}{51}$ & $\frac{3.8-5.2}{4.7}$ & 35 & 23 & $\begin{array}{c}0.2 \\
7 \\
\end{array}$ & $\mathrm{~V}$ \\
\hline
\end{tabular}

In terms of complexity of the geological structure, the Beskempir field is referred to the $3^{\text {rd }}$ group. The study of the main regulatory and technical production documentation revealed that over $1200 \mathrm{~m}$ the roadway was supported according to category IV. Approved regulatory documentation is made on the basis of all the requirements for choosing the type of support. Although the researched object is not entirely complex structurally.

\section{Results and discussion}

Strengthened support is used in unstable host rocks. Analyzing the sources [18], [19], it can be noted that the most common types of supports in complex conditions are combined supports. Such supports can bear high rock pressure from overlying rocks, both at deep and shallow levels, where high pressure results not only from the weight of a rock column, but also from structural disturbance of rocks.

To ensure trouble-free driving in conditions of high rock pressure and structural instability of host rocks, the support must meet the following requirements: high strength and rigidity in the area of established rock pressure, and flexibility in the face zone.

Current practice of construction of underground works reveals that the speed of driving depends on the type and material of support, technology and the degree of mechanization of its construction. And this in turn affects the cost of the facility and the timing of its commissioning. One of the ways to reduce the cost of support of mine workings is the use of combined support.

The analysis of the world practice of supporting underground mine workings as well as the results of patent research, it was found that up to $30 \%$ of capital investments spent on driving the mine workings are spent on their supporting [20][21].

Thus, an in-depth study of the design documentation for the Beskempir field revealed that the horizontal excavation (haulage roadway at $+230 \mathrm{~m}$ ) intersects two tectonic faults. This significantly complicates its construction and stipulates the selection of support category III. At the same time, this roadway has a significant impact on the main mining parameter: productivity, labor intensity, cost of ore mining as well as the safety.

In order to select the optimal type and justify the design of the horizontal support as well as to determine the duration of the main tunneling operations, a detailed study of the mining geological and mining engineering conditions along the mining route was carried out. Figure 1 shows the tectonic fault zones that were identified during a detailed study of the haulage roadheading at the $+230 \mathrm{~m}$ level of the Beskempir field.

A detailed analysis of the field's opening scheme revealed that the haulage roadway passes through two faults (No. 2 and No. 3). Furthermore, an area of destroyed rocks is formed above the working in the form of a regular $138 \times 138 \times 138 \mathrm{~m}$ triangle (Fig. 1 ) 


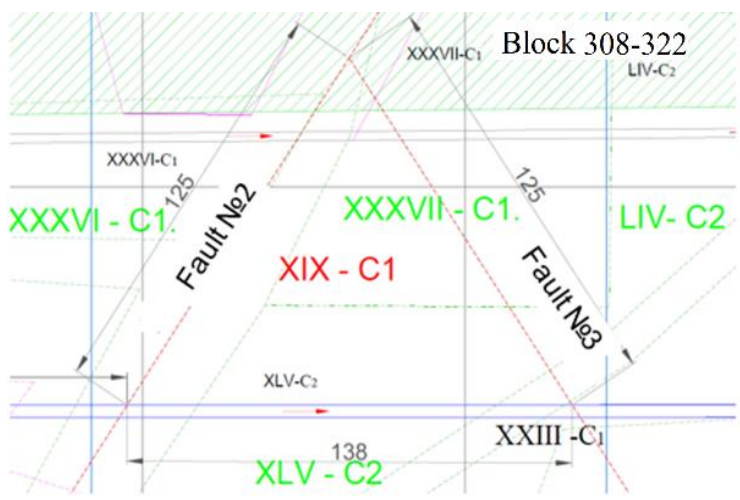

Figure 1. Parameters of contours of rock mass fault in the area of location of the workings

To specify the boundaries of the fractured zone, we have studied the software packages PLAXIS 8.2; Examine 2D. A comparative analysis led to the selection of the Examine 2D program (Table 2).

Table 2. Established fault zones

\begin{tabular}{|c|c|c|c|c|}
\hline \multicolumn{2}{|c|}{$\begin{array}{c}\text { Dimensions } \\
\text { of the working, } m\end{array}$} & \multirow{2}{*}{ 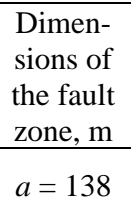 } & \multirow{2}{*}{$\begin{array}{c}\text { Dimensions } \\
\text { of stress } \\
\text { spread, } \mathrm{m}\end{array}$} & \multirow{2}{*}{$\begin{array}{c}\text { Max } \\
\text { stress, } \\
\mathrm{MPa}\end{array}$} \\
\hline $\begin{array}{l}\text { Working's } \\
\text { area }\end{array}$ & $S=10.9 \mathrm{~m}^{2}$ & & & \\
\hline $\begin{array}{l}\text { Working's } \\
\text { length }\end{array}$ & $L=1300$ & $b=138$ & $\begin{array}{l}\text { from } 0 \\
\text { to } 52\end{array}$ & $\begin{array}{c}\text { from } 30 \\
\text { to } 90\end{array}$ \\
\hline $\begin{array}{l}\text { Working's } \\
\text { width }\end{array}$ & $B=3.4$ & $c=138$ & $\begin{array}{c}\text { From } \\
0 \text { to } 152\end{array}$ & $\begin{array}{c}\text { from } 30 \\
\text { to } 120\end{array}$ \\
\hline
\end{tabular}

The program is interactive and easy to use, ideal for quick parametric analysis, preliminary design, and as a training tool in numerical stress analysis in geotechnical problems [22][23].

The stress deformed state around the working's contour containing two tectonic faults was investigated within the estimated area shown in Figure 2.

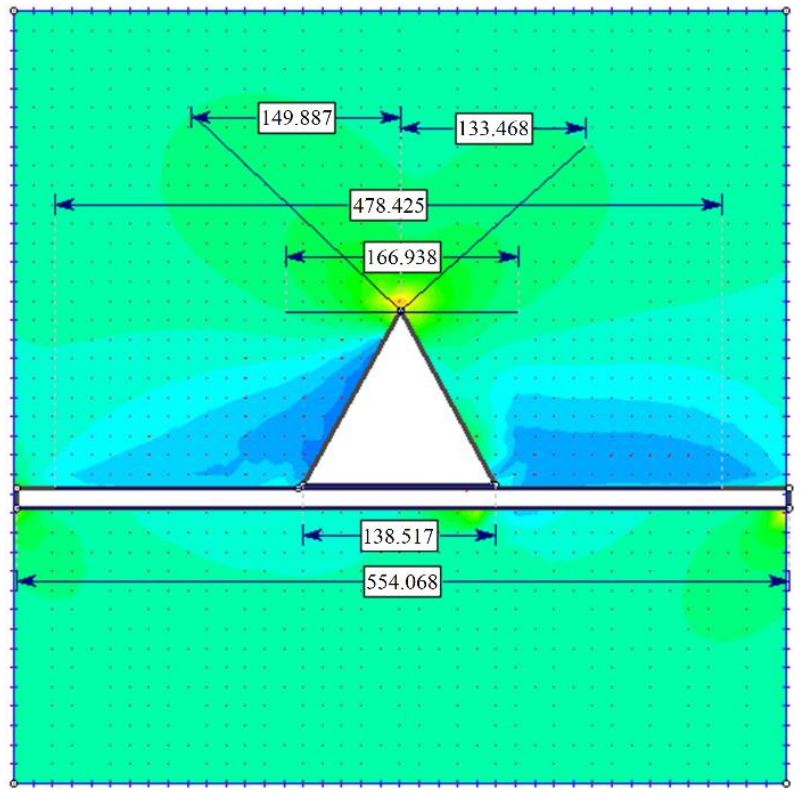

Figure 2. Model of spread of the rock mass stress deformed state
To identify the zone of the rock mass stress deformed state, the basic input data were entered into the Examine 2D program, as a result of which the zones of spread of the rock mass deformations around the working's contour were determined. This program ensured the monitoring of rocks behavior in the tectonic fault zone of the haulage roadway at the $+230 \mathrm{~m}$ level.

The approximation of the estimated area of the rock mass was performed using finite elements.

Taking into account the available symmetry, the largest disturbed section of the working in the estimated area was considered where faults No. 2 and No. 3 intersect forming the regular triangle. The size of the estimated area is: $a=138 \mathrm{~m}$, $b=138 \mathrm{~m}, c=138 \mathrm{~m}$ (along the $X, Y$ axes respectively).

At the initial stage of research, a natural stress state of the rock mass was formed within the estimated area with due account for tectonic disturbance.

The resulting stress deformed state of the rock mass was the source data for the subsequent stages of the calculation.

Modeling of the haulage roadway was performed in the following sequence:

- stage 1: determination of zones of the unstable part of the rock mass with due account for the size of the tectonic fault along the length of the working;

- stage 2: determination of the instability zone of the rock mass with due account for the rock mass fracturing;

- stage 3: determination of the zone of spread of stable and unstable rock mass of the haulage roadway.

Thus, as a result of the research, the zones of spread of the rock mass deformations around the working's contour were identified, i.e. the modeling ensured the monitoring of rocks behavior in the fault zone. Based on the model of spread of the rock mass stress deformed state, the researched object was divided into three sections depending on the rock mass stability (Fig. 3 and 4).

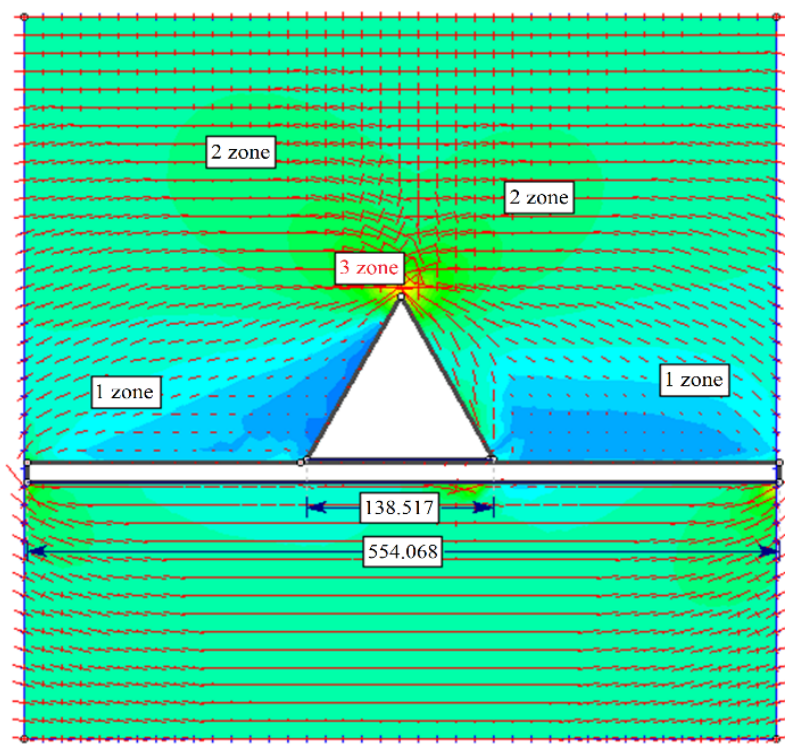

Figure 3. Model of spread of the rock mass stress deformed state with due account for its fracturing

With the purpose of detailed analysis of the researched object and optimal selection of the type of support, cores around 308-322 blocks were extracted, which provided additional source data on the physical and mechanical properties of the rocks around the haulage roadway. 


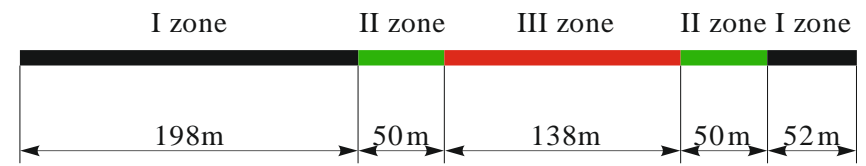

Figure 4. Distribution of zones depending on the categories of rock mass stability

Strength tests of these samples were done in a geological laboratory on a special press by means of crushing. On the basis of laboratory data, displacement [24], [25] around the working was determined, which also proves the presence of a fault (Fig. 5 and 6).

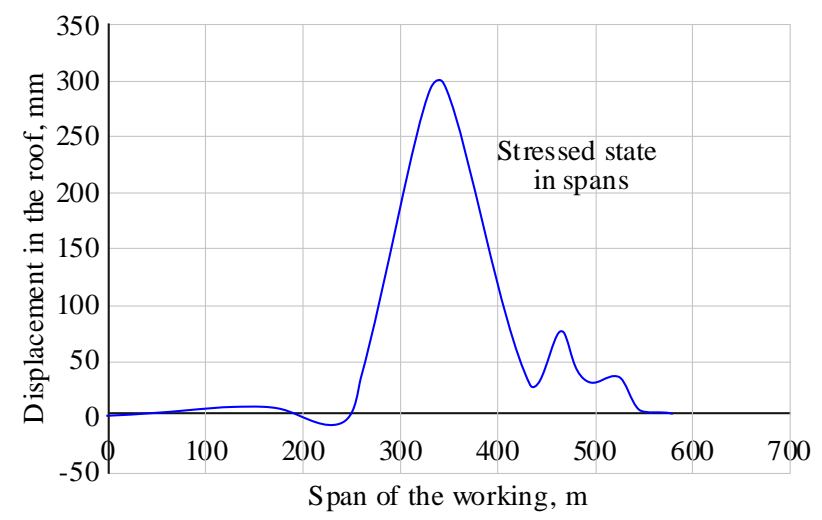

Figure 5. Estimated displacement in the roof of the haulage roadway according to Professor M.M. Protodyakonov's method

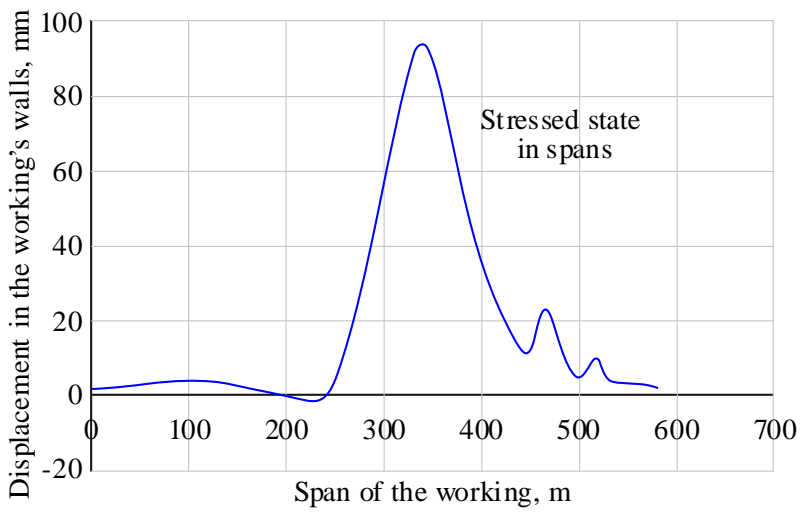

Figure 6. Estimated displacement in the walls of the haulage roadway according to Professor M.M. Protodyakonov's method

The type of support for a horizontal mine working is traditionally selected depending on the stability category (Table 3 ), the criteria of which account for the displacement value $U$.

According to this method, the categories of mine working's stability are determined according to the absolute value of the maximum rock displacements on the cross-sectional contour, which are determined differentially in the mine working's roof, bottom and walls. The maximum displacement value of the investigated object corresponds to support category IV (Fig. 7).

It is evident that the maximum displacement value is valid over a length of about $300 \mathrm{~m}$, and the rest of the values are much lower.

Table 3. Criteria for determining rock stability categories in compliance with the traditional method (according to Construction Norms and Rules II -94-80)

\begin{tabular}{|c|c|c|c|c|}
\hline \multirow[b]{2}{*}{$\begin{array}{c}\text { Rock stability } \\
\text { category }\end{array}$} & \multirow[b]{2}{*}{$\begin{array}{c}\text { Assessed } \\
\text { rock stability }\end{array}$} & \multicolumn{3}{|c|}{ Displacement $U, \mathrm{~mm}$} \\
\hline & & $\begin{array}{c}\text { Sedimentary rocks (sand- } \\
\text { stones, siltstones, argil- } \\
\text { lites, limestones, coal, etc.) }\end{array}$ & $\begin{array}{l}\text { Igneous rocks } \\
\text { (granites, diorites, } \\
\text { porphyrites, etc.) }\end{array}$ & $\begin{array}{c}\text { Saliferous rocks (rock } \\
\text { salt, sylvinite, carnallite, } \\
\text { etc.) }\end{array}$ \\
\hline $\mathrm{I}$ & stable & up to 50 & up to 20 & up to 200 \\
\hline II & medium stable & over 50 to 200 & over 20 to 100 & over 200 to 300 \\
\hline III & unstable & over 200 to 500 & over 100 to 200 & over 300 to 500 \\
\hline
\end{tabular}

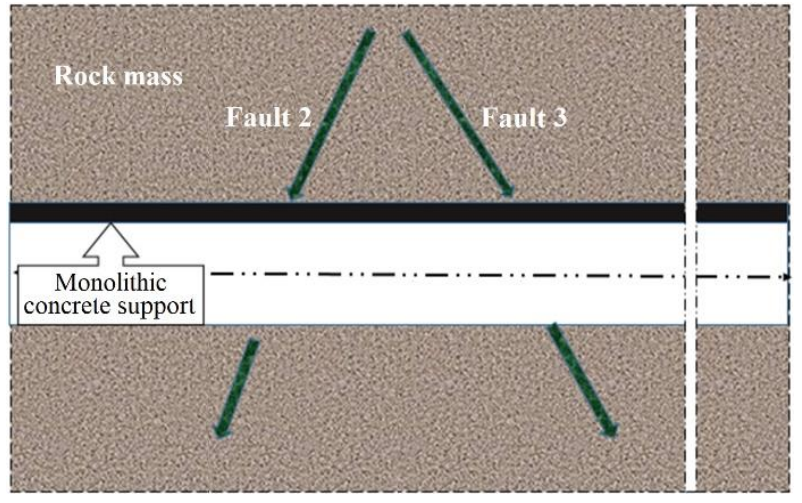

Figure 7. Accepted support design. Monolithic concrete support with a $200 \mathrm{~mm}$ concrete thickness in the attic zone of the mine working, and $300 \mathrm{~mm}$ thickness in the walls (concrete class B15)

Although the total length of the mine working is $1300 \mathrm{~m}$, about $600 \mathrm{~m}$ of which is classified as fragmented and highly unstable section of the rock mass.
The selected category of support for the haulage roadway is not rational because the existing displacement values are not uniform. To assess the rock stability in the researched object, we use Barton's Q-system [26][27]. The particularity of this method ensures the impact assessment of such factors as rock strength and quality, development depth, cross section of mine workings and stress state in the surrounding rock mass, the number and condition of fractures, including the degree of their alteration. Therefore, Barton's Q-system is more suitable for the conditions of our facility and allows the determination of stability of the researched roadway (Table 4 ).

Classification of rocks by stability relative to Q-rating intervals and their correspondence to stability categories (Table 5 and 6).

Based on the above-mentioned Barton's Q-system, with due account for the rocks stability parameters, various types of support are recommended for each section of the investigated object (roadway), the span of an individual structure of which also depends on the value of the stress deformed state of the section (Fig. 5). 
Table 4. Classification of rocks by stability relative to $Q$-rating intervals

\begin{tabular}{cccc}
\hline Q-rating & $\begin{array}{c}\text { Description } \\
\text { of the rock mass }\end{array}$ & $\begin{array}{c}\text { Category according } \\
\text { to Mining Rules }\end{array}$ & $\begin{array}{c}\text { Stability } \\
\text { degree }\end{array}$ \\
\hline $0.01-0.001$ & $\begin{array}{c}\text { exceptionally soft } \\
\text { extremely soft }\end{array}$ & V & very unstable \\
$0.01-0.1$ & very soft & IV & unstable \\
$0.1-1.0$ & soft & III & medium stable \\
$1-4$ & medium & II & stable \\
$4-10$ & hard & I & very stable \\
$10-40$ & very hard & & \\
$40-100$ &
\end{tabular}

Table 5. Recommended types of support by rock stability categories in compliance with Barton's Q-system

\begin{tabular}{|c|c|c|}
\hline $\begin{array}{l}\text { Rock stability } \\
\text { category }\end{array}$ & Type of development & Type of support \\
\hline Very stable (I) & $\begin{array}{l}\text { Capital development } \\
\text { Temporary and non-capital } \\
\text { development }\end{array}$ & $\begin{array}{c}\text { Shotcrete at least } 30 \mathrm{~mm} \text { thick. } \\
\text { In junction points: anchors + shotcrete } \\
\text { No support required (if life of the mine working does not exceed } 5 \text { years). } \\
\text { In junction points: anchorage }\end{array}$ \\
\hline Stable (II) & $\begin{array}{l}\text { Capital development } \\
\text { Temporary and non-capital } \\
\text { development }\end{array}$ & $\begin{array}{c}\text { Combined (anchors + shotcrete). } \\
\text { In junction points: combined (anchors + wire net- or } \\
\text { fiber-reinforced shotcrete at least } 50 \mathrm{~mm} \text { thick) } \\
\text { Shotcrete at least } 50 \mathrm{~mm} \text { thick. } \\
\text { In junction points: combined (anchors + shotcrete) }\end{array}$ \\
\hline Medium stable (III) & $\begin{array}{l}\text { Capital development } \\
\text { Temporary and non-capital } \\
\text { development }\end{array}$ & $\begin{array}{l}\text { Composite (anchors + wire netting + shotcrete at least } 50 \mathrm{~mm} \text { thick). } \\
\text { Instead of wire netting it is allowed to use fiber-reinforced } \\
\text { shotcrete at least 50-90 mm thick } \\
\text { Combined (anchors + shotcrete at least } 50 \mathrm{~mm} \text { thick) } \\
\text { In junction points: combined (anchors + wire netting + shotcrete } \\
\text { at least } 50 \mathrm{~mm} \text { thick). Instead of wire netting it is allowed } \\
\text { to use fiber-reinforced shotcrete at least } 50-90 \mathrm{~mm} \text { thick }\end{array}$ \\
\hline Stable (IV) & All types of development & $\begin{array}{l}\text { Metal arch support + shotcrete. Monolithic concrete support. } \\
\text { Composite (anchors + wire netting + fiber-reinforced shotcrete) }\end{array}$ \\
\hline Very stable $(\mathrm{V})$ & All types of development & $\begin{array}{l}\text { Special drivage methods are required to change the rock category into } \\
\text { higher stability category, i.e. the application of compressible support in } \\
\text { combination with forepoling and protective support }\end{array}$ \\
\hline
\end{tabular}

Table 6. Recommended types of support and its gap from the face in compliance with Barton's Q-system

\begin{tabular}{|c|c|c|}
\hline $\begin{array}{c}\text { Rock stability } \\
\text { category }\end{array}$ & Type of support & Permissible support gap from the face \\
\hline I & $\begin{array}{l}\text { No support } \\
\text { Shotcrete } \\
\text { Anchor }\end{array}$ & $\begin{array}{c}\text { Not specified } \\
\text { Up to } 100 \mathrm{~m} \\
\text { In junction points: not more than } 1 \mathrm{~m}\end{array}$ \\
\hline II & $\begin{array}{c}\text { Shotcrete } \\
\text { Combined } \\
\text { (anchors and shotcrete) } \\
\end{array}$ & $\begin{array}{l}\text { Up to } 10 \mathrm{~m} \\
\text { Anchors not more than } 0.8-1 \mathrm{~m} \text {, shotcrete up to } 10 \mathrm{~m}\end{array}$ \\
\hline III & $\begin{array}{l}\text { Composite (anchors with wire } \\
\text { netting and shotcrete) }\end{array}$ & $\begin{array}{c}\text { The first layer of shotcrete is applied without any gap. } \\
\text { Then anchors and net are installed, and another layer of shotcrete } \\
\text { is applied on the net with a } 0.8-1 \mathrm{~m} \text { gap }\end{array}$ \\
\hline IV & $\begin{array}{c}\text { Metal arch support }+ \text { shotcrete } \\
\text { Monolithic concrete support } \\
\text { Combined (anchors and monolithic } \\
\text { concrete or metal arch support) } \\
\text { Composite (anchors + netting + } \\
\text { thick shotcrete) } \\
\end{array}$ & $\begin{array}{l}\text { Shotcrete without any gap, arch support up to } 1 \mathrm{~m} \\
\text { Up to } 1 \mathrm{~m} \\
\text { Anchors without any gap. } \\
\text { Monolithic concrete or metal arch support: up to } 1 \mathrm{~m} \\
\text { Anchors and net without any gap. } \\
\text { Shotcrete without any gap } \\
\end{array}$ \\
\hline V & $\begin{array}{c}\text { Metal arch support } \\
\text { Monolithic concrete support } \\
\text { Combined (rock bolting and } \\
\text { monolithic concrete or metal arch } \\
\text { support) } \\
\text { Composite (resin-grouted roof } \\
\text { bolts + netting }+ \\
\text { thick shotcrete) } \\
\end{array}$ & $\begin{array}{l}\text { No gap is permitted. Special drivage methods are required } \\
\text { to change the rock category into higher stability category } \\
\text { (i.e. the application of forepoling or rock injection) }\end{array}$ \\
\hline
\end{tabular}

Notes:

1)when driving in the rocks of different stability, including in tectonic fault zones, the gap of support should be accepted depending on the weakest rocks;

2) the gap of support is indicated at the time of drilling provided high-quality roof scaling and wall trimming and availability of drilling and blasting permit from the mine overseer. 
The performed tests confirmed the appropriateness of span and category of support for the researched object and revealed advantages in comparison with the selection of support using the traditional method. The improved type of support corresponds to the stress deformed state in the fault zone, forming a set of individual support structures (Fig. 8).

The accepted thickness of the shotcrete support in the stable part of the mine working is at least $3 \mathrm{~mm}$. The shot concrete support is used as a basic support. In the zone with stability category II and III, the basic support is used in combination with anchors of different sizes. In the weakened zones (stability category II), the thickness of shotcrete support is not less than $5 \mathrm{~mm}$. In the fragmented unstable zone, the thickness of shotcrete is 5-9 mm. For support the zone of stability category III, an additional metal mesh is used. When using the support with metal mesh, anchors and shotcrete, the shotcrete must cover the metal mesh completely. The metal mesh should be made of a metal 4-6 mm bar (mesh size: $10 \times 10 \mathrm{~cm})$.

The anchor support is used in combination with the basic support in rocks of stability categories II and III. The parameters of the anchor support are selected on the basis of the main dimensions of the mine working, and are as follows: bolt length $1.8-2.5 \mathrm{~m}$, the anchor density: $1.39 \mathrm{pcs} / \mathrm{m}^{2}$, the distance between anchors in a row and rows of bolts: $0.85 \cdot 0.85 \mathrm{~m}$.

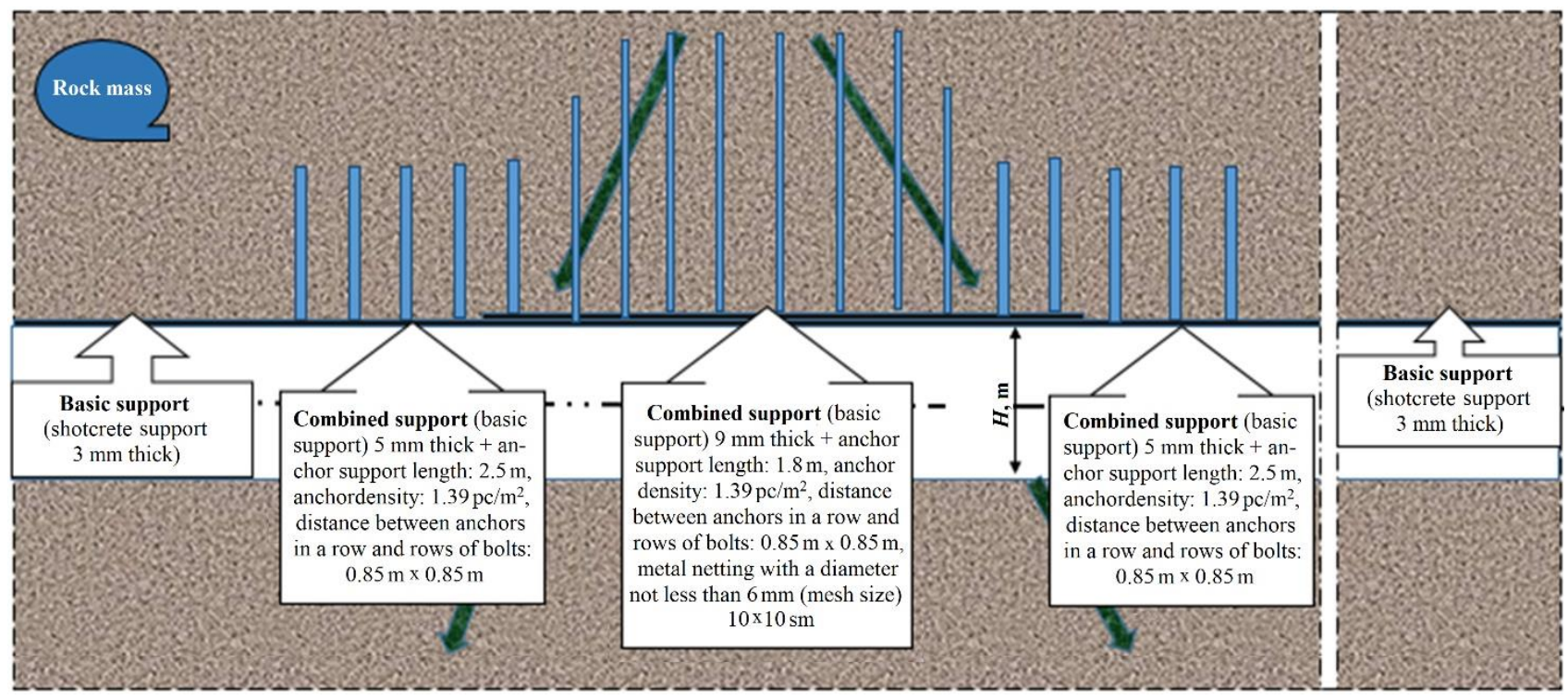

Figure 8. Recommended type of support with adjustable resistance along the mine working

\section{Conclusions}

Underground operations in prone to cave-in and unstable rock masses limit the use of energy-intensive equipment and technologies. In turn, this situation leads to a sharp decrease in labor productivity and safety at mineral resource development. The use of traditional supports at roadheading and supporting of underground mine workings in complex geological conditions requires large labor and financial investments and cannot ensure a safe working environment.

As a result of a detailed analysis of the stress deformed state of the rock masses in the fault zone, four typical sections were identified. And depending on the degree of the stress deformed state of rocks, it was recommended to use a specific design of support with adjustable resistance in each zone. The implementation of support with adjustable resistance allows to exclude unreasonable safety factor of support in areas with favorable mining and geological conditions and to prevent its destruction and repeated supporting in adverse conditions due to the timely increase in bearing capacity.

Support with adjustable resistance is a combination of individual support structures and their combinations installed along the mine with optimal parameters for its various sections determined on the basis of continuous monitoring of the rock contour displacement. The support with adjustable resistance in our case includes the basic support (shotcrete) and reinforced supports (combined support).
Thus, based on the preliminary data from the abovementioned study, it is possible to monitor the stress deformed state of the rocks around the mine working. The studies of physical and mechanical characteristics and spread of the stress deformed state with due account for the fault around the mine working lead to the following conclusion. It was established that $41.6 \%$ of the mine working with due account for the fault zone is unstable, and $58 \%$ of it is a more stable part. This means that stress state changes drastically throughout the mine development. The largest part of the mine working is reliable, although according to the project it is completely supported (100\%) in compliance with category III (monolithic concrete support). A certain stress deformed state ensures the adjustment of the support's length with due account for specific data. In line with these values it is recommended to use the specific design of support with adjustable resistance, where only $23 \%$ of the mine working length corresponds to support category III. Thanks to the use of such supports, it becomes possible to control the rock pressure in the complex mining geological conditions of the Beskempir field.

The recommended support with adjustable resistance ensures the increase in the strength and safety of the entire structure, the reduction of labor-intensity and cost of structures as well as the increase in the manufacturability of operations. 


\section{Acknowledgements}

The results of these studies were obtained partially thanks to the support of Joint-Stock Company "AK Altynalmas".

\section{References}

[1] Baibatsha, A. (2011). Geological models of formation and industrial types of gold deposits in kazakhstan. International Multidisciplinary Scientific Geoconference and EXPO - Modern Management of Mine Producing, Geology and Environmental Protection. (1), 133-138. https://doi.org/10.5593/sgem2011/s01.118

[2] Luzin, B.S. (2001). Mine "ABS-Balkhash": The leader of gold mining in Kazakhstan. Gornyi Zhurnal, (11), 78-80.

[3] On Gold Mining in Kazakhstan: Particularities and Outlooks of Development. (2019). Retrieved from https://prodragmetally.ru/

[4] Aiva. Gold Mining in Africa, Russia and Kazakhstan. (2019). Retrieved from https://musthaveforyou.mediasole.ru/

[5] Luzin, B.S., \& Golik, V.I. (2004). The prospects of gold mining development in Kazakhstan. Izvestiya Vysshikh Uchebnykh Zavedenij. Tsvetnaya Metallurgiya, (3), 11-16

[6] Sagers, M.J. (1998). Gold production in Central Asia. Post-Soviet Geography and Economics, 39(3), 125-150.

[7] Haynes, P.E. (2008). A Eulogy for the Underground Workings of the Gold Hill Mine: Tooele County, Utah. Rocks \& Minerals, 83(5), 451456. https://doi.org/10.3200/rmin.83.5.451-456

[8] Tsvetkov, V.K., \& Prikhod'ko, V.D. (1992). Rational shape of the cross section of an underground mine working. Journal of Mining Science, 28(2), 156-159. https://doi.org/10.1007/bf00710735

[9] Kolesnyk, V., Pavlychenko, A., Borysovs'ka, O., \& Buchavyy, Y. (2018). Formation of Physic and Mechanical Composition of Dust Emission from the Ventilation Shaft of a Coal Mine as a Factor of Ecological Hazard. Solid State Phenomena, (277), 178-187. https://doi.org/10.4028/www.scientific.net/ssp.277.178

[10] Vladyko, O., Kononenko, M., \& Khomenko, O. (2012). Imitating modeling stability of mine workings. Geomechanical Processes During Underground Mining, 147-150. https://doi.org/10.1201/b13157-26

[11] Zhdankin, N.A., \& Kolokolov, S.B. (1989). Rational shape of a rock exposure in underground workings. Soviet Mining Science, 25(3), 248-252. https://doi.org/10.1007/bf02528483

[12] Majcherczyk, T., Małkowski, P., \& Niedbalski, Z. (2008). Rock mass movements around development workings in various density of standing-and-roof-bolting support. Journal of Coal Science and Engineering (China), 14(3), 356-360. https://doi.org/10.1007/s12404-008-0078-1

\section{Аналіз напружено-деформованого стану порід навколо транспортного штреку родовища "Бескемпір" (Казахстан)}

\section{А. Бегалінов, Т. Алменов, Р. Жанакова, Б. Бектур}

Мета. Дослідження та детальний аналіз напружено-деформованого стану (НДС) гірських порід навколо транспортного штреку на основі чисельного моделювання для вибору раціонального типу і конструкції кріплення транспортного штреку родовища "Беспемпір".

Методика. Використано комплексний метод дослідження: аналіз і узагальнення літературних джерел 3 вивчення НДС гірських порід масиву, вдосконалення технології кріплення гірничих виробок; натурних і лабораторних випробувань при дослідженні та визначенні міцності зразків гірських порід; застосування математичної статистики та обробки експериментальних даних у програмних продуктах. Чисельне моделювання НДС виконано в програмі Ехатіne 2D з урахуванням утвореної області зруйнованих порід у вигляді правильного трикутника зі сторонами $138 \times 138 \times 138$ м. Для оцінки стійкості порід використовували методику Бартона (Q-рейтинг).

Результати. Виконано чисельне моделювання НДС гірських порід в зоні тектонічного розлому транспортного штреку на горизонті +230 м і визначено зони поширення деформацій масиву навколо контуру виробки. Побудовано графіки зміщення порід покрівлі та боків транспортного штреку й встановлено, що максимальні зміщення проявляються протягом зони тектонічного розлому. Виявлено зони нестійкості масиву, зони нестійкості масиву з урахуванням тріщинуватості масиву виробки, зони поширення стійких і нестійких масивів транспортного штреку. Встановлено, що виробка з урахуванням розлому має протяжність нестійкої частини масиву $41.6 \%$, а більш стійка частина виробки - 58\%. Запропоновано протяжність транспортного штреку розділити на 3 ділянки за стійкістю гірських порід з певним видом кріплення.

Наукова новизна. Для умов родовища “Бескемпір" у транспортному штреку на основі вивчення НДС масиву гірських порід виявлено характерні ділянки за стійкістю, що дозволило визначити конкретну конструкцію кріплення регульованого опору (КРО).

Практична значимість. Застосування КРО залежно від стійкості масиву гірських порід, дозволяє мінімізувати витрати на кріплення штреку і підтримання протяжних ділянок виробки, а також підвищити безпеку ведення гірничих робіт у конкретних гірничо-геологічних умовах Бескемпірського родовища.

Ключові слова: напружено-деформований стан, породний масив, кріплення, зона розлому, конструкція кріплення, будівництво, тектонічні розломи, підземні виробки
13] Project “Joint Development of Beskempir and Aksakal Mines” (Stage I). (2001). Astana, Kazakhstan: Production Association Ore Mining Amanzholov, D.B., \& Bakhramov, B.A. (2012). Enhancing the development of gold-bearing ore of Akbakay ore field. Mining Magazine of

Russian Federation: Publishing House "Gornaya Kniga".
16] Makarov, A.B. (2006). Practical geomechanics. Moscow, Russian Federation: Publishing House "Gornaya Kniga".

7] Bukhartsev, N.B., \& Volkov, Ye.N. (2013). Impact of faults on stress

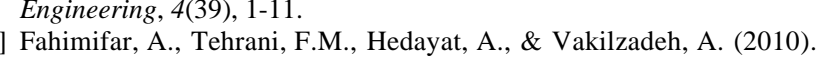
Analytical solution for the excavation of circular tunnels in a viscohttps://doi.org/10.1016/j.tust.2010.01.002

rock masses in the conditions of tectonic impact. News of TulSU. Earth Sciences, (4), 292-304.

Pankratenko, A.N., Pleshko, M.V., \& Nasonov, A. derground object with anchor-concrete support. Electronic Scientific Magazine “Don's Engineering Bulletin”, (3), 1-13.

21] Pleshko, M.S., Voynov, I.V., \& Nasonov, A.A. (2017). Research of Electronic Scientific Magazine "Don's Engineering Bulletin”, (3), 1-9.

[22] Begalinov, A.B., Serdaliyev, Ye.T., \& Abakanov, A.T. (2013). Solving geomechanical tasks using ANSYS Software. Mining Magazine of round mine

25] Results of geotechnical surveys of rocks of the Akbakay Mining and Metallurgical Company. (2009). Order No. 302, No. 339, No. 78.

NMT. Proceedings of the International Symposium on Sprayed Con-
Not crete, $46-66$.

[27] Grimstad, E., Kankes, K., Bhasin, R., Magnussen, A., \& Kaynia, A. (2002). Rock mass quality q used in designing reinforced ribs of Symposium on Sprayed Concrete, 134-142. and Underground Space Technology, 25(4), 297-304. 


\section{Анализ напряженно-деформированного состояния пород вокруг транспортного штрека месторождения “Бескемпир” (Казахстан)}

\section{А. Бегалинов, Т. Алменов, Р. Жанакова, Б. Бектур}

Цель. Исследование и детальный анализ напряженно-деформированного состояния (НДС) горных пород вокруг транспортного штрека на основе численного моделирования для выбора рационального типа и конструкции крепи транспортного штрека месторождения “Бескемпир".

Методика. Использован комплексный метод исследования: анализ и обобщение литературных источников по изучению НДС горных пород массива, совершенствованию технологии крепления горных выработок; натурных и лабораторных испытаний при исследовании и определении прочности образцов горных пород; применению математической статистики и обработки экспериментальных данных в программных продуктах. Численное моделирование НДС выполнено в программе Ехатіne 2D с учетом образованной области разрушенных пород в виде правильного треугольника со сторонами $138 \times 138 \times 138$ м. Для оценки устойчивости пород использовали методику Бартона (Q-рейтинг).

Результаты. Выполнено численное моделирование НДС состояния горных пород в зоне тектонического разлома транспортного штрека на горизонте +230 м и определены зоны распространения деформаций массива вокруг контура выработки. Построены графики смещение пород кровли и боков транспортного штрека и установлено, что максимальные смещение проявляются на протяжении зоны тектонического разлома. Выявлены зоны неустойчивости массива, зоны неустойчивости массива с учетом трещиноватости массива выработки, зоны распространения устойчивых и неустойчивых массивов транспортного штрека. Установлено, что выработка с учетом разлома имеет протяженность неустойчивой части массива $41.6 \%$, а более устойчивой части выработки - 58\%. Предложено протяженность транспортного штрека разделить на 3 участка по устойчивости горных пород с определенным видом крепления.

Научная новизна. Для условий месторождения “Бескемпир” в транспортном штреке на основе изучения НДС массива горных пород выявлены характерные участки по устойчивости, что позволило определить конкретную конструкцию крепи регулируемого сопротивления (КРС).

Практическая значимость. Применение КРС в зависимости от устойчивости массива горных пород позволяет минимизировать затраты на крепление штрека и поддержание протяженных участков выработки, а также повысить безопасность ведения горных работ в конкретных горно-геологических условиях Бескемпирского месторождения.

Ключевые слова: напряженно-деформированное состояние, породный массив, крепление, зона разлома, конструкиия крепи, строительство, тектонические разломы, подземные выработки

\section{Article info}

Received:16 May 2019

Accepted: 10 June 2020

Available online: 25 June 2020 